\title{
Pemeriksaan Telinga Hidung Tenggorok Pada Siswa SDN 16 Mataram
}

\author{
Eka Arie Yuliyani*1, Rika Hastuti Setyorini ${ }^{2}$, Eva Triani ${ }^{3}$, \\ Didit Yudhanto ${ }^{4}$, Indana Eva Ajmala ${ }^{5}$ \\ 1,4Bagian Ilmu Kesehatan THT-KL, Fakultas Kedokteran Universitas Mataram \\ ${ }^{2}$ Bagian Ilmu Kesehatan Masyarakat, Fakultas Kedokteran Universitas Mataram \\ ${ }^{3}$ Bagian Parasitologi, Fakultas Kedokteran Universitas Mataram \\ ${ }^{5}$ Bagian Paru, Fakultas Kedokteran Universitas Mataram
}

Kata Kunci:

Pemeriksaan

THT, Serumen,

Anak sekolah

dasar

\begin{abstract}
Abstrak: Latar Belakang: Serumen merupakan hasil produksi dari kelenjar sebasea dan apokrin di kulit liang telinga yang secara fisiologis terbentuk. Pada kondisi tertentu serumen dapat menyebabkan masalah kesehatan dimana terdapat penumpukan serumen di liang telinga dalam jumlah banyak sehingga berakibat pada timbulnya gangguan dengar yang disebut dengan serumen obturan. Penumpukan serumen di dalam liang telinga ini dapat terjadi pada semua usia baik dewasa maupun anak-anak dengan prevalensi yang cukup tinggi dan menjadi penyebab utama dari masalah kesehatan berupa gangguan dengar. Gangguan dengar pada anak sekolah ini tentunya akan memberikan dampak yang sangat penting terhadap tingkat prestasi belajar anak di sekolah karena anak akan sulit untuk menerima pelajaran. Tujuan: Kegiatan pengabdian pada masyarakat ini bertujuan untuk memberikan pelayanan kesehatan berupa pemeriksaan THT pada siswa SDN 16 Mataram kelas 4 dan 5 sehingga diharapkan adanya upaya yang dapat dilakukan secara perorangan dalam rangka pencegahan penyakit pada telinga dan menjaga kebersihan serta kesehatan telinga. Metode: Kegiatan pengabdian ini dilakukan selama satu hari dimana pada kegiatan tersebut dilakukan pemeriksaan telinga hidung dan tenggorok pada siswa SDN 16 Mataran kelas 4 dan 5 kemudian hasil pemeriksaan dicatat dan dilaporkan serta dilakukan tindakan pembersihan telinga. Hasil: Pada kegiatan ini didapatkan data dari 83 orang siswa kelas 4 dan 5 yang dilakukan pemeriksaan kesehatan THT didapatkan 42 orang $(50,60 \%)$ mengalami penumpukan serumen di kedua telinga dan telah dilakukan tindakan pembersihan telinga, infeksi telinga luar 1 orang $(1,20 \%)$, infeksi kronis telinga tengah 1 orang $(1,20 \%)$ dan sisanya 37 orang dalam batas normal. Kesimpulan: Masalah penumpukan serumen di kalangan anak-anak sekolah dasar masih menjadi masalah kesehatan dan sangat perlu untuk dilakukan program kegiatan pembersihan telinga secara rutin.
\end{abstract}

\section{Korspodensi email: yuliyani.eka@gmail.com}

\section{PENDAHULUAN}

Kotoran Telinga atau dalam bahasa kedokteran yang disebut dengan serumen merupakan hasil produksi dari kelenjar sebasea dan apokrin di kulit liang telinga yang secara fisiologis terbentuk. ${ }^{1}$ Serumen atau kotoran telinga secara fisiologis juga memiliki fungsi untuk menghalangi serangga yang dapat masuk ke dalam telinga dan sebagai pelumas sehingga dapat mencegah kekeringan akan tetapi tidak memiliki sifat sebagai anti jamur dan anti bakteri. ${ }^{2}$ Penumpukan serumen di dalam liang telinga ini dapat terjadi pada semua usia baik dewasa maupun anak-anak dengan prevalensi yang cukup tinggi dan menjadi penyebab utama dari masalah kesehatan berupa gangguan dengar., ${ }^{3,4}$ Adapun beberapa faktor yang dapat menyebabkan kondisi penumpukan serumen adalah variasi anatomi liang telinga, jumlah kelenjar yang bervariasi, serta faktor individu sendiri karena cara membersihkan telinga yang salah. ${ }^{2}$ 
Berdasarkan survei yang dilakukan di beberapa sekolah di enam kota di Indonesia yang dilakukan oleh Profesi perhati FK UI, menunjukkan bahwa prevalensi serumen obturan pada anak sekolah cukup tinggi yaitu antara 30-50\%. Selain itu, masih banyak masyarakat yang kurang peduli terhadap kebersihan telinga. ${ }^{5}$ Gangguan dengar pada anak sekolah ini tentunya akan memberikan dampak yang sangat penting terhadap tingkat prestasi belajar anak di sekolah karena anak akan sulit untuk menerima pelajaran dimana dengan mendengar anak dapat menyerap $20 \%$ informasi lebih besar daripada membaca. ${ }^{5}$

Dengan demikian sangat perlu untuk dapat dilakukan upaya preventif dan promotif kepada anak-anak sekolah mengenai pentingnya menjaga kebersihan dan kesehatan telinga yang benar serta upaya perubahan perilaku. Selain itu perlu dilakukan upaya memberikan pelayanan terhadap kesehatan telinga dan upaya rehabilitatif terhadap anak usia sekolah.

\section{METODE KEGIATAN}

Perilaku untuk menjaga kesehatan perorangan termasuk menjaga kebersihan telinga pada anak-anak sekolah dasar khususnya di SDN 16 Mataram cukup rendah, sehingga perlu dilakukan upaya memberikan pelayanan kesehatan berupa pemeriksaan THT pada anak-anak sekolah dasar. Kegiatan ini sangat berguna untuk memberikan pelayanan kesehatan serta pendidikan tentang pentingnya kebersihan telinga secara langsung dan tidak langsung kepada siswa sekolah dasar, sehingga diharapkan adanya upaya yang dapat dilakukan secara perorangan dalam rangka pencegahan penyakit pada telinga dan menjaga kebersihan serta kesehatan telinga.

Kegiatan pengabdian masyarakat ini dilaksanakan dalam bentuk pelayanan kesehatan berupa pemeriksaan THT pada anak-anak sekolah dasar sekaligus memberikan informasi mengenai cara membersihkan telinga yang baik dan benar. Pemeriksaan THT dilakukan pada siswa/i SDN 16 Mataram kelas 4 dan 5 dengan menggunakan alat-alat pemeriksaan THT yang disediakan oleh pelaksana kegiatan. Kondisi telinga, hidung dan tenggorok yang didapatkan pada pemeriksaan akan dicatat dan kemudian di analisis secara deskriptif menggunakan Microsoft Excel dan disajikan serta dilaporkan dalam bentuk Grafik dan narasi.

\section{HASIL DAN PEMBAHASAN}

Target kegiatan pengabdian ini adalah siswa kelas 4 dan 5 SDN 16 Mataram yang berjumlah 90 orang siswa. Pada saat pelaksanaan kegiatan, siswa yang ikut serta dalam kegiatan berjumlah 83 orang siswa. Kegiatan dilakukan di dalam ruangan kelas dan dilakukan pemeriksaan THT oleh dokter spesialis THT yang juga merupakan anggota kegiatan pengabdian ini.

Selain itu, dilakukan pula pencatatan dan pelaporan hasil pemeriksaan dimana diperoleh data bahwa pada pemeriksaan telinga didapatkan distribusi siswa yang mengalami penumpukan serumen di kedua telinga adalah sebanyak 42 orang siswa $(50,6 \%)$, penumpukan serumen pada satu sisi sebanyak 2 orang $(2,4 \%)$, infeksi telinga luar 1 orang $(1,2 \%)$, infeksi kronis telinga tengah 1 orang $(1,2 \%)$ dan sisanya $37(44,6 \%)$ orang dalam batas normal. Pada pemeriksaa hidung didapatkan data 4 orang $(4,8 \%)$ menderita rinitis akut, 
1 orang $(1,2 \%)$ rinosinusitis akut dan 78 orang lainnya $(94 \%)$ dalam batas normal. Pada pemeriksaan tenggorok didapatkan data tonsillitis kronis 28 orang $(33,7 \%)$ dan 55 orang lainnya $(66,3 \%)$ dalam batas normal.

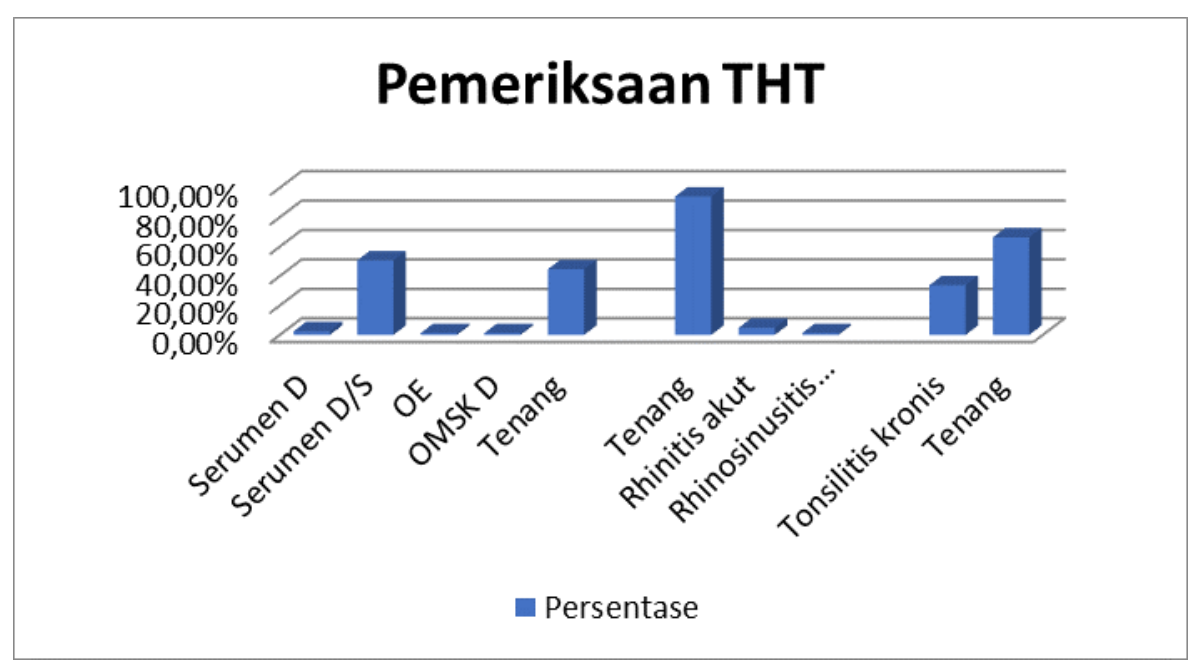

Gambar 1. Grafik Hasil Pemeriksaan THT

Hasil tersebut menunjukkan bahwa masalah penumpukan serumen di kalangan anakanak sekolah dasar masih menjadi masalah kesehatan dan sangat perlu untuk dilakukan program kegiatan pembersihan telinga secara rutin.

Menurut Kemenkes, 2010 serumen obturan atau sumbatan kotoran telinga merupakan penyebab utama dari gangguan pendengaran pada 9,6 juta orang di Indonesia. ${ }^{5}$ Berdasarkan Survei kesehatan Indra Penglihatan dan Pendengaran tahun 1994-1996 data Indonesia juga menunjukkan morbiditas yang tinggi yaitu penyakit telinga $18,5 \%$, prevalensi gangguan pendengaran $16,8 \%$ sedangkan ketulian didapatkan pada $0,4 \%$ populasi dan paling tinggi pada kelompok usia sekolah 7-18 tahun. ${ }^{6}$ Hasil kegiatan pemeriksaan kesehatan yang dilakukan Puskesmas Mertoyudan I di wilayah kerjanya pada anak sekolah juga mendapatkan bahwa sekitar 20-30\% siswa mengalami gangguan kesehatan khususnya pendengaran. ${ }^{7}$

Prestasi anak sekolah sangat dipengaruhi faktor internal yaitu yang berasal dari dirinya sendiri, dimana salah satunya adalah panca indera. Memiliki panca indera yang sehat dalam hal ini adalah telinga, maka siswa akan dapat mengikuti proses pembelajaran dengan baik dan meningkatkan daya tangkap serta daya serap siswa dalam menerima materi di sekolah. ${ }^{7}$ Beberapa hasil penelitianpun mendapatkan bahwa tingkat pendengaran seseorang yang telah dibersihkan telinganya dari serumen obsturan akan memiliki perbaikan tingkat pendengaran menjadi lebih baik yang ditandai dengan perbaikan pada skor audiogramnya. ${ }^{8}$ 

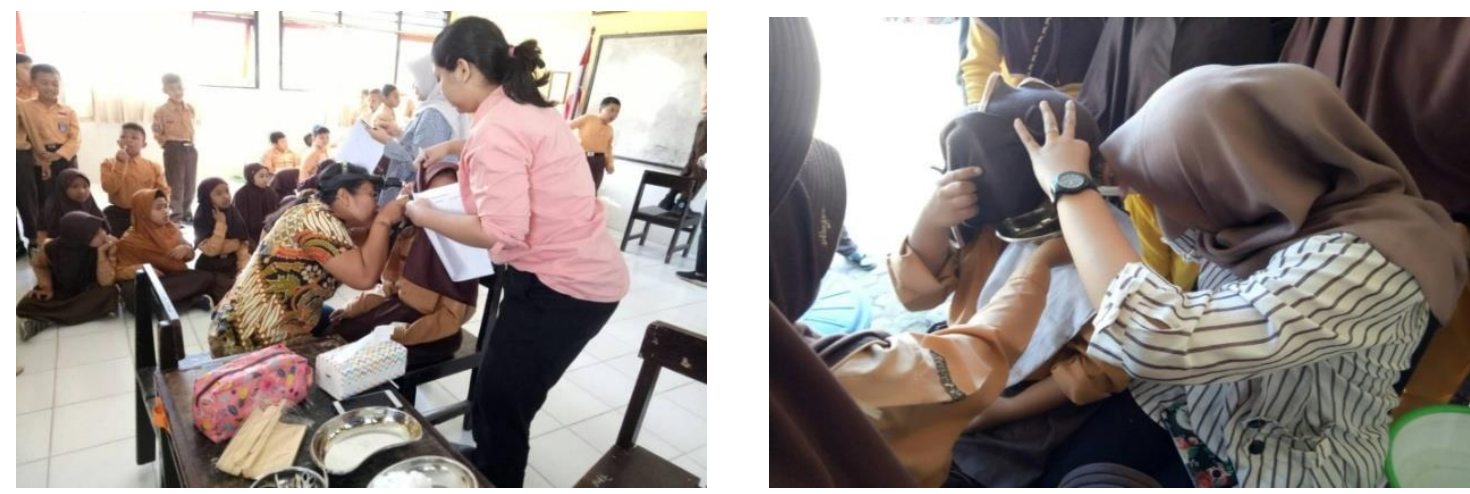

Gambar 2. Foto Pelaksanaan Kegiatan

\section{KESIMPULAN DAN SARAN}

Penumpukan serumen di kalangan anak-anak sekolah dasar masih menjadi masalah kesehatan di bidang THT-KL, sehingga dengan demikian sangat perlu untuk dilakukan upaya pengembangan program kegiatan pembersihan telinga secara rutin untuk anak-anak sekolah dasar untuk mencegah terjadinya gangguan dengar pada anak-anak sekolah dasar yang dapat mempengaruhi prestasi belajarnya.

\section{UCAPAN TERIMA KASIH}

Penulis mengucapkan terima kasih kepada Kepala sekolah, para guru dan siswa SDN 16 Mataram yang telah memberikan ijin dan dukungan pada kegiatan pengabdian ini. Terima kasih kepada Lembaga Penelitian dan Pengabdian Kepada Mayarakat (LPPM) Universitas Mataram yang telah memberikan dukungan financial terhadap pengabdian ini. Terima kasih pula kepada Teman Sejawat, mahasiswa kedokteran, dan Bagian Keterampilan Medik di Fakultas Kedokteran Universitas Mataram serta seluruh pihak yang telah membantu dalam pelaksanaan kegiatan pengabdian ini.

\section{DAFTAR PUSTAKA}

1. Melinda, N.M. 2017. Analisis Faktor Yang Mempengaruhi Pembentukan Serumen Obsturan Pada Pasien Rawat Jalan Di Poliklinik THT RSUD DR. Soeroto Ngawi Tahun 2016. Surakarta: Fakultas Kedokteran Universitas Muhammadiyah Surakarta.

2. Jung, T.T.K. dan Tae, H.J. 2003. Diseases of The External Ear. Dalam: Snow, J.B. dan Ballenger, J.J., penyunting. Ballenger's Otorhinolaryngology Head and Neck Surgery. Edisi ke-16. Ontaroi: BC Decker Inch. h. 233-34.

3. Sutji, P., Riskiana, D. dan Syahrijuita. 2012. Perbandingan efektitifitas beberapa pelarut terhadap kelarutan cerumen obsturan secara in vitro. Ina J-Otolaryngol-Head and Neck Surg. 42:23-7.

4. Kementrian Kesehatan Republik Indonesia. 2010. Telinga Sehat Pendengaran Baik. Jakarta: Kementrian Kesehatan RI. 
5. Martini, E., Ari, P., Dewi, P. dan Sumardiyono. 2017. Skrining dan Edukasi Gangguan Pendengaran pada Anak Sekolah. Indonesian Journal On Medical Science. 4(1):110-18.

6. Selviyanti, A.S, Armenius, S., R.E.C., Tumbel. Kesehatan Telinga Pada Anak SMA Negeri 9 Manado. Jurnal e-Clinic. 4(1):275-78.

7. Widiyanto,P., dan Eka,L.M. 2015. Pengaruh Pengambilan Serumen Terhadap Peningkatan Prestasi Belajar Pada Siswa Sekolah Dasar di Wilayah Kerja Puskesmas Mertoyudan I Kabupaten Magelang. Journal of Holistic Nursing. 1-8

8. Alriyanto, C.Y. dan Awal, P. 2010. Pengaruh Serumen Obsturan Terhadap Gangguan Pendengaran. Program Pendidikan Sarjana Kedokteran Fakultas Kedokteran Universitas Diponegoro. Semarang.. 